\title{
SOME FACTORS AFFECTING PASTURE PRODUCTION IN SOUTHLAND
}

\author{
W. H. RISK \\ Scientist, $M A F$, Invercargill \\ T. E. LUDECKE \\ Senior Lecturer, Lincoln College
}

Abstract

The pattern of production from permanent pastures on two major soil groups in Southland and some factors affecting production are discussed.

Production was shown to be lower on the summer droughtprone YGE/YBE intergrade soils compared with the wetter southern YBE. The major proportion $(80 \%)$ of the production occurred in spring and summer. Grasses contributed two-thirds and white clover one-third of the annual production.

Inadequate mineral nitrogen levels in soils over the spring result in seasonal responses to nitrogen fertilizers.

The use of high rates of nitrogen fertilizer at regular intervals throughout the year increased total pasture production by about $\mathbf{2 5} \%$.

The clover cyst nematode was shown to reduce white clover establishment and production in field trials.

\section{INTRODUCTION}

THE Two major soil groups which occur in eastern Southland and on the Southland Plains are the yellow-grey to yellow-brown earth intergrades and the southern yellow-brown earths which are derived from greywacke alluvium and loess. The yellow-grey/ yellow-brown intergrade soils are found in areas where the mean annual rainfall is 900 to $1000 \mathrm{~mm}$ and summer droughts are common. They have a massive, very firm fragipan at 40 to $50 \mathrm{~cm}$, above which is a mottled B horizon caused by a perched water table in the wetter months. Mole and tile drainage is essential. The southern yellow-brown earths are found in higher rainfall areas where the mean rainfall is 1000 to $1250 \mathrm{~mm}$. These soils are friable in both the $\mathrm{A}$ and $\mathrm{B}$ horizons, with no signs of impeded drainage.

This paper reports annual and seasonal pasture production from well-topdressed Ruanui ryegrass and Huia white cloverbased pastures on these two soil groups. The following factors were studied: 
1. Summer soil moisture deficits.

2. Inorganic soil nitrogen levels as related to the seasonal use of nitrogen fertilizers.

3. The regular use of nitrogen fertilizers throughout the year.

4. Clover cyst nematode.

\section{EXPERIMENTAL DETAILS}

The details of the two trial sites are as follows:

Site 1: Yellow-grey/yellow-brown intergrade (Aparima silt loam) at Aparima, $10 \mathrm{~km}$ north of Otautau. The trial area was a' 3.5-ha paddock which was grazed as part of a 120-ha property stocked at 16 ewes/ha (Guise, 1976; Risk, 1976). The paddock was mole- and tile-drained.

Site 2: Southern yellow-brown earth (Waikiwi silt loam) at the MAF Woodlands Research Station $20 \mathrm{~km}$ north-east of Invercargill (Bruce, 1977). The pasture production data were collected from the following treatments in a nitrogen fertilizer grazing trial:

1. N.O-No nitrogen fertilizer;

2. N.1-100 kg N/ha/yr (50 kg N/ha applied 1 March and 1 September) ;

3. N.2-400 kg N/ha/yr (50 kg N/ha every 46 days).

The nitrogen fertilizer was applied as calcium ammonium nitrate. The trial was set stocked with the pasture maintained at a height of 2.5 to $3 \mathrm{~cm}$ by regularly adjusting the numbers of stock. Stocking rate varied from 8 to 34 ewes/ha throughout the year.

Pastures at both sites were sown in the autumn of 1971 after a summer fallow, They were harvested by the standard rate of growth technique with a 3-weekly cutting interval except over the winter period (Lynch, 1960).

At both sites three small uncultivated fallow areas were created and maintained by the use of paraquat.

Soil moisture levels in fallow soils and soils under pasture were monitored at 3-weekly intervals in both the 1973-4 and 1974-5 seasons (1 June to 31 May) at the Aparima site and in the 1974-5 season at the Woodlands site.

Soil inorganic nitrogen levels (ammonium, $\mathrm{NH},-\mathrm{N}$ and nitrate, $\mathrm{NO}_{3} \mathrm{~N}$ ) were monitored at 3-weekly intervals in both fallow soils and soils under pasture, at both sites, in the 1974-5 season. At the Woodlands site the N.O treatment only was sampled. The depths of sampling for the soil moisture levels and the inorganic $\mathrm{N}$ levels were 0 to 10,10 to 20,20 to 40 and 40 to $60 \mathrm{~cm}$. 


\section{PASTURE PRODUCTION ON THE APARIMA SOIL}

The mean annual and seasonal dry matter production (4-year average) and the production from the grass arid clover components of the sward are shown in Table 1. The mean annual dry matter production was $10210 \div 900 \mathrm{~kg} / \mathrm{ha}$.

TABLE 1: MEAN ANNUAL AND SEASONAL DRY MATTER PRO. DUCTION FROM GRASSES AND WHITE CLOVER ON THE APARIMA SOIL (kg/ha) $(1973 / 74-1976 / 77)$

\begin{tabular}{lrrr} 
& Grass & $\begin{array}{c}\text { White } \\
\text { Clover }\end{array}$ & Total \\
\hline Winter & 390 & 90 & 480 \\
Spring & 3550 & 1360 & 4910 \\
Summer & 240 & 1190 & 3430 \\
Autumn & 1040 & 350 & 1390 \\
Total & 7220 & 2990 & 10210 \\
& & \pm 1900
\end{tabular}

As Radcliffe (1974) reported, and the standard deviation indicates, the variation in total production is considerable. Spring production (September-November) amounted to almost $50 \%$ of the total production and reached a rate of about $80 \mathrm{~kg} / \mathrm{ha} / \mathrm{day}$ in November 1973 and 1974 (Fig. 1).

There is a marked decline in summer production, mainly due to a drop in grass production (Table 1). Autumn and winter production amounted to only $14 \%$ and $5 \%$, respectively, of the total production. Ryegrass was the dominant grass at this site and

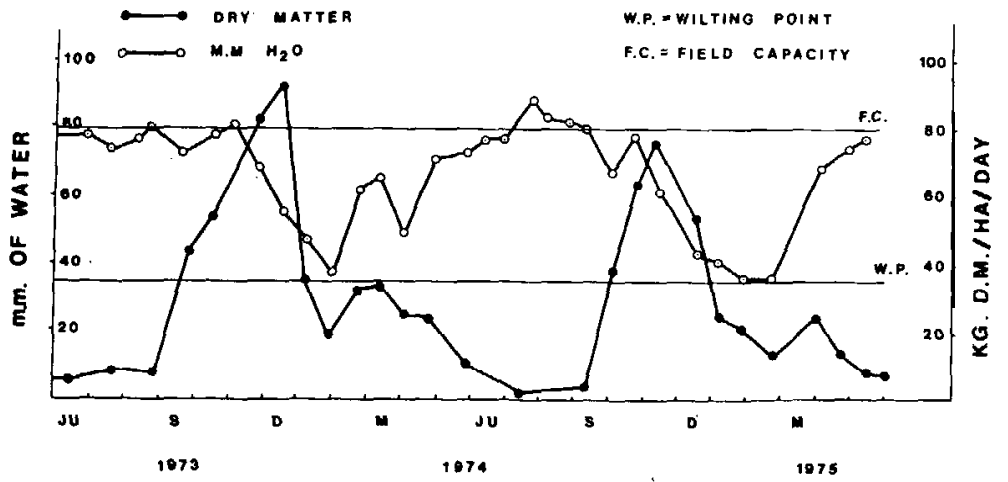

FIG. 1: Soil moisture levels $0-20 \mathrm{~cm}(\mathrm{~mm})$ and dry matter production (kg/ha/day) on an Aparima soil from June 1973 to May 1975. 
produced $75 \%$ of the total grass production. This is probably due to the winter management policy of all-grass wintering practised on this farm (Guise, 1976). The clover dry matter production was $30 \%$ of the total yield, with the bulk of growth occurring in the spring and summer.

The dry matter yield of the roots at this site showed that the total production to $90 \mathrm{~cm}$ was $4380 \mathrm{~kg} / \mathrm{ha}$, with $75 \%$ in the top $20 \mathrm{~cm}$ (Risk, 1976). In view of this, the moisture levels in the 0 to $20 \mathrm{~cm}$ depth were determined from June 1973 to May 1975 and are shown in Fig. 1. The pasture production in $\mathrm{kg} \mathrm{DM} / \mathrm{ha} /$ day over this period is also shown. The plant-available water levels declined in November of both 1973 and 1974 and reached wilting point. Associated with this is the marked decline in dry matter production from about $80 \mathrm{~kg} / \mathrm{ha} /$ day in November to about $20 \mathrm{~kg} / \mathrm{ha} /$ day in January-February. On this soil, summer pasture production appears to be severely limited by droughts in some years at least.

In the fallow soil, levels of $\mathrm{NH}_{4}-\mathrm{N}$ were negligible during 1974-5. The levels of $\mathrm{NO}_{3}-\mathrm{N}$ in the fallow treatments fluctuated markedly throughout the season (Fig. 2.) and show a very distinctive pattern of downward movement over the autumn and vinter. It seems likely that the $\mathrm{NO},-\mathrm{N}$ is mainly lost laterally through mole drains situated at about $40 \mathrm{~cm}$ deep rather than through the impermeable fragipan. Between June 6, 1974 and September 11,

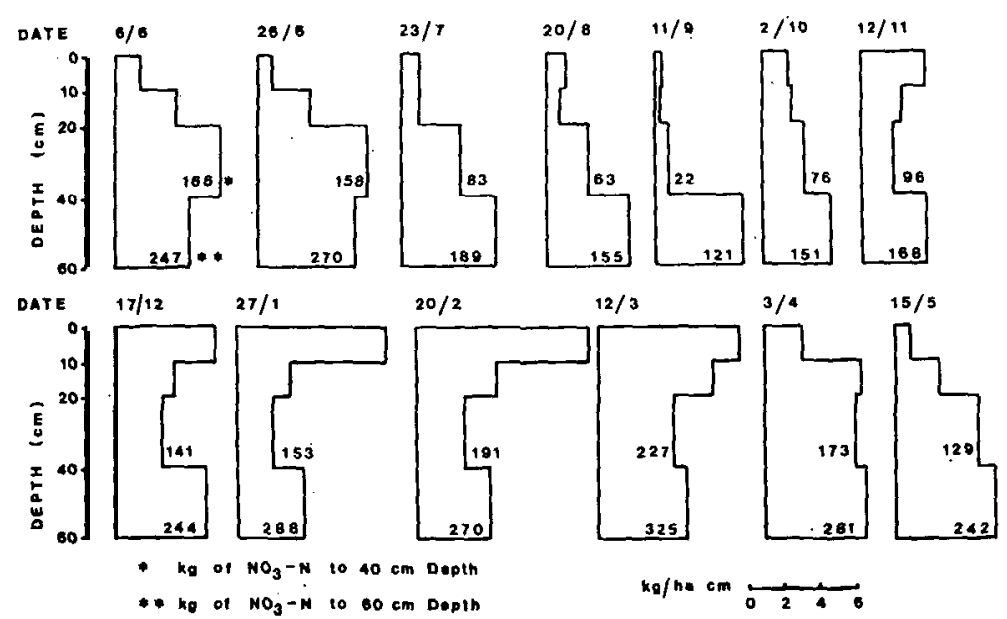

Fig. 2: Soil nitrate levels ( $\mathrm{kg} / \mathrm{ha}$ of $N$ ) in a fallow Aparima soil from June 1974 to May 1975. 
$1974,144 \mathrm{~kg} \mathrm{~N} / \mathrm{ha}$ was lost from the top $40 \mathrm{~cm}$ of the soil. These losses are similar to those reported by Tham (1971) and Ludecke (1974) . This indicates that soils should not be left fallow over autumn and winter months or large losses of nitrogen will occur.

The levels of NO,-N and NH,-N under the, pasture were negligible during all seasons of the year, indicating that the pasture or microbes had utilized all the mineralized nitrogen.

As shown in Fig. 2, there was no major increase in the NO,-N levels in the surface horizons in the fallow until NovemberDecember. The peak pasture production in both seasons (Fig. 1) corresponded with this period of increasing net mineral nitrogen release in the fallow treatment. These data suggest that pasture production earlier in the spring is limited by nitrogen deficiency. This observation was supported by regular responses to fertilizer nitrogen in the spring at this and other sites in Southland (Risk, 1978).

\section{PASTURE PRODUCTION ON THE WAIKIWI SOILS}

The mean annual dry matter production from the no nitrogen fertilizer treatment (N.0) was $12530 \pm 1840 \mathrm{~kg} / \mathrm{ha}$ (Fig. 3). Variation in production between seasons is considerable. Grass production amounted to $62 \%$ of the total, and clover $37 \%$. Ryegrass was again the dominant grass, producing $63 \%$ of the grass yield. This is a high level of pasture production similar to those reported by Harris (1960) and Radcliffe (1974). In the N.0 treatment, $40 \%$ of the production occurred in the spring, $42 \%$ in the summer, $15 \%$ in the autumn, and only $3 \%$ in the winter.

There was no significant response to the application of 100 $\mathrm{kg} / \mathrm{ha} / \mathrm{yr}$ of nitrogen (N.1), but a significant response to the application of $400 \mathrm{~kg} / \mathrm{ha} / \mathrm{yr}$ of nitrogen (N.2). The mean response to the N.1 treatment was only $810 \mathrm{~kg} / \mathrm{ha}$ of dry matter, and to the N.2 treatment was $2830 \mathrm{~kg} / \mathrm{ha}$. There was no significant effect of the N.l or N.2 treatments on total spring or summer dry matter producion. It certainly would not be economic to apply $400 \mathrm{~kg} / \mathrm{ha}$ of nitrogen to obtain the increase of $2830 \mathrm{~kg} / \mathrm{ha}$ of dry matter. The current cost of buying $400 \mathrm{~kg} / \mathrm{ha}$ of nitrogen as urea, the cheapest nitrogen fertilizer, is $\$ 178$.

The N.1 and N.2 treatments produced highly significant effects on the total grass production (Fig. 3). The responses were most marked in the spring and summer. The increase in the spring production was $1180 \mathrm{~kg} / \mathrm{ha}$ in the N.1 treatment and $2960 \mathrm{~kg} / \mathrm{ha}$ in the N.2 treatment. The N.2 treatment over the summer produced 


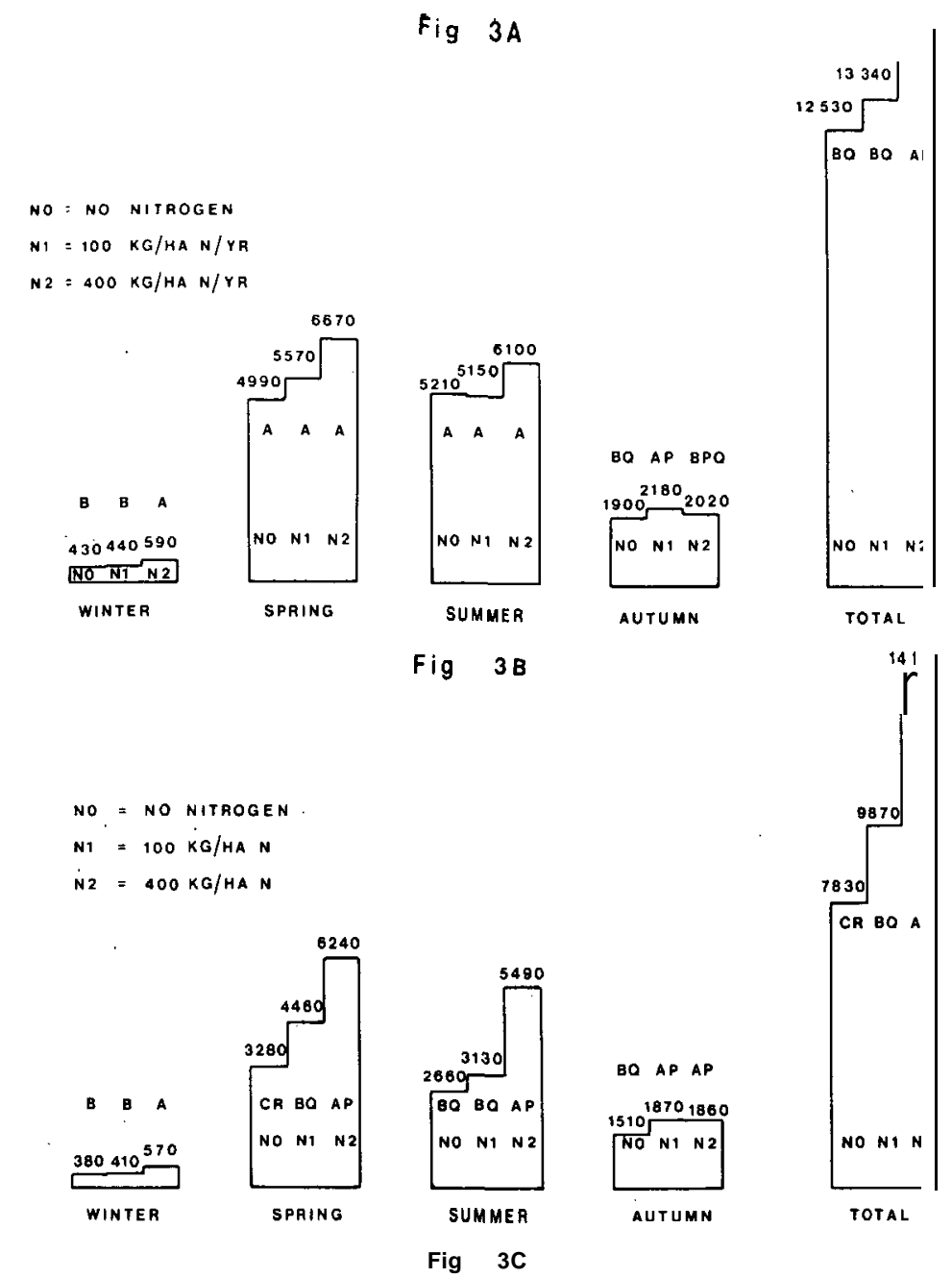

$\triangle P$ BO $C R$

4580

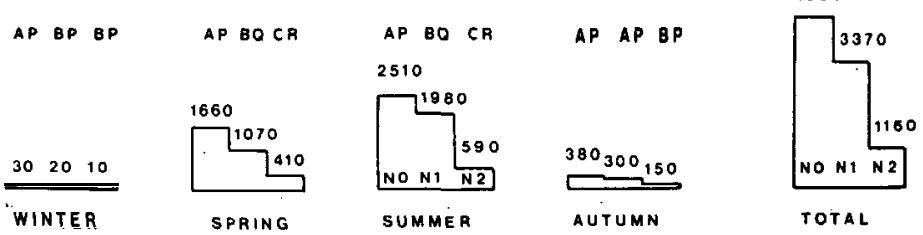

FIG. 3: Mean dry matter pasture production $(1973 / 74-1976 / 77)$ in $\mathrm{kg} / \mathrm{ha}$ on a Waikiwi soil.

FIG. 3A: Mean annual and seasonal total production.

FIG. 3B: Mean annual and seasonal grass production.

Fig. 3C: Mean annual and seasonal clover production.

$$
\text { (A-C P }<0.05 \text {, P-R P }<0.01 \text { ) }
$$


a significant increase of $2830 \mathrm{~kg} / \mathrm{ha}$ of dry matter. The responses were very small in the autumn.

Clover production was markedly depressed by the application of nitrogen fertilizer (Fig. 3.). The depression in clover production nullified the marked increases in grass production so that the increases in total dry matter production were relatively small. It must be stressed that the measurements in this grazing experiment were made under a set stocking system of grazing management with pastures being maintained at a height of 2.5 to 3.0 $\mathrm{cm}$. The pasture measurement sites were only excluded from grazing for 3 weeks while dry matter production cuts were made.

Pasture root distribution was similar to that reported in the Aparima soil. Soil moisture levels to $20 \mathrm{~cm}$ at this site in the 1974-5 season did not decline until January and did not approach wilting point. Pasture production was maintained in November and December at about $80 \mathrm{~kg} / \mathrm{ha} / \mathrm{day}$, but then there was a gradual decline to $35 \mathrm{~kg} / \mathrm{ha} /$ day by mid-February. This resulted in the summer production being very similar to the spring production in the N.0 treatment (Fig. 3.). Soil moisture conditions on this yellow-brown earth do not affect pasture production to nearly the same extent as on the drier Aparima intergrade soil.

The levels of $\mathrm{NO}_{3}-\mathrm{N}$ in the fallow Waikiwi soil also fluctuated markedly throughout the season. The NO,-N levels under pasture were very low in the spring-early summer period, again suggesting that the pasture had utilized all the mineral nitrogen. The levels -of NO,-N in the surface horizons in the fallow soil did not increase appreciably until December, with maximum levels in January and February. This resulted in the pastures also suffering from nitrogen deficiencies in the spring-early summer period, and resulted in the large nitrogen fertilizer responses reported previously.

\section{EFFECT OF THE CLOVER CYST NEMATODE ON} WHITE CLOVER PRODUCTION

Surveys in recent years have shown that the clover cyst nematode (Heterodera trifolii) is widespread in developed agricultural soils in Southland. Under glasshouse conditions this organism has been shown to depress considerably the production of both seedling and established white clover (Healy et al., 1973) . In New Zealand, prior to this study, the effects of the organism on white clover establishment and growth in the field were unknown.

In September and October 1973 a field trial was laid down to investigate the chemical control of $H$. trifolii. The site was an old runout pasture with a low white clover content on a Waikiwi 
TABLE 2: NEMATICIDE TRIAL DRY MATTER YIELDS SEPTEMBER 1973-DECEMBER 1974 (kg/ha)

\begin{tabular}{lccc}
\hline & Grass & Clover & Total \\
\hline Control & 7670 & 1240 & 8910 \\
& $\mathrm{P}$ & $\mathrm{Q}$ & 0 \\
Mocap* & 7400 & 1290 & 8700 \\
Moc'ap + Nemagon** & $\mathrm{P}$ & 0 & 0 \\
& 7570 & 2300 & 9870 \\
& $\mathrm{P}$ & $\mathrm{P}$ & $\mathrm{Q}$ \\
\hline
\end{tabular}

*Mocap $=10 \%$ granular O-ethyl S,S. dipropyl phosphorodithioate.

* *Nemagon = 1,2.dibrom-3-chloropropene.

Duncan's Multiple Range Test: Means without a common letter differ significantly $\mathrm{P}$ and $\mathrm{Q}, P<0.01$.

silt loam at the Woodlands Rescarch Station. There were three treatments (Table 2). Dry matter production cuts were taken from September 28, 1973 to December 17, 1974. Cyst numbers in the control plots were a mean of 17.7 per core $(25 \mathrm{~mm} \times 75$ $\mathrm{mm})$.

The cysts had to be reduced to very low numbers $(<1$ per core) before there was an increase in clover growth. This occurred only in the mocap + nemagon treatment, where there was an $85 \%$ increase in clover. production. The cyst numbers in the mocap only treatments were 6.0 per core and there was no significant increase in clover production (Risk, 1976).

It was also shown in a clover establishment trial at the Woodlands site that the clover cyst nematode reduced clover seedling vigour and growth. The harmful effects of the organism at establishment can be controlled by pelleting the seed with a $10 \%$ loading of Carbofuran (2,3-dihydro 2,2-dimethylbenzo-furan-7 yl methyl carbamate) .

Heterodera trifolii in pastures can be controlled with suitable chemicals applied at a suitable stage in the life cycle of the organism. On a farm scale, the high cost of chemicals and the problem of a satisfactory application method make their use on pasture uneconomic and impractical at present. A more satisfactory means of control would be the breeding of resistant, or at least tolerant, strains of white clover.

\section{CONCLUSION}

Mean dry matter production on the Aparima soil (intergrade YGE/YBE) was $10200 \mathrm{~kg} / \mathrm{ha}$, and on the Waikiwi soils 12500 $\mathrm{kg} / \mathrm{ha}$, which is $2300 \mathrm{~kg} / \mathrm{ha}$ greater. This increase occurred over 
the summer-early autumn period when the soil moisture status was much better in the Waikiwi soil. At both sites $80 \%$ of the total production occurred in the spring and summer. On both soils about two-thirds of the total production was from grasses and one-third from the white clover.

Levels of mineral nitrogen in uncultivated fallow soils at both sites showed that net mineralization does not increase appreciably until November-December, with maximum rates in January-February. The levels of mineral nitrogen under pastures were very low throughout the year, indicating that all available mineral nitrogen was utilized.

Assuming similar net mineralization rates in the two stations, the low levels recorded in the spring under fallow indicates nitrogen deficiencies for maximum pasture production. This was substantiated by responses to nitrogen fertilizers over the spring.

In a grazing experiment on the Waikiwi soil the regular application of nitrogen fertilizer $(400 \mathrm{~kg} / \mathrm{ha} / \mathrm{year})$ increased grass production but depressed clover production, Annual herbage production was consequently increased by $22.5 \%$.

White clover establishment and growth was shown in field trials to be adversely affected by clover cyst nematode: The only practical way of controlling this organism is by plant breeding.

\section{ACKNOWLEDGEMENTS}

We wish to thank Mr R. F. McLenaghen, Lincoln College, and the MAF Research Division technical staff in Invercargill, for assistance. We would also like to express our thanks to $\mathrm{Mr}$ J. T. B. Guise and the staff of the Woodlands Research Station for assistance with the field trials.

\section{REFERENCES}

Bruce, I. G., 1977. N.Z. Soil Survey Report No. 32.

Guise, J. T. B., 1976. Proc. 26th Linc. Coll. Fmrs' Conf.: 143-6.

Harris, A. J., 1960. Proc. N.Z. Grassld Ass., 22: 53-63.

Healy, W. B.; Widdowson, J. P.; Yeates, G. W., 1973. N.Z. $J l$ agric. Res. 16: $70-6$.

Ludecke, T. E., 1974. Proc. Agron. Soc. N.Z., 4: 27-9.

Lynch, P. B., 1960. N.Z. Dept Agric. Bull, No. 399: 154.

Radcliffe, J. E., 1974. N.Z. Jl exp. Agric., 2: 341-8.

Risk, W. H., 1976. M.Agr.Sc. Thesis, Lincoln College Library, p. 161. 1978. In The Place of Nitrogen Fertilisers in New Zealand

Agriculture (ed. P. B. Lynch). N.Z. Inst. Agric. Sci., Wellington (in press).

Tham, K. C., 1971. M.Agr.Sc. Thesis, Lincoln College Library, p. 103. 